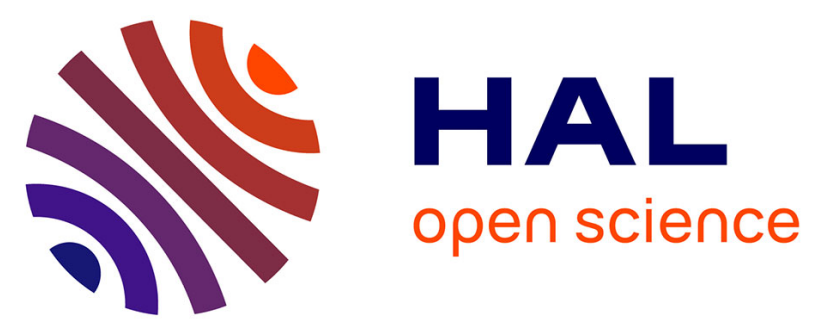

\title{
Regime shifts of Mediterranean forest carbon uptake and reduced resilience driven by multidecadal ocean surface temperatures
}

J. Carnicer, C. Domingo-marimon, M. Ninyerola, J. Camarero, A. Bastos, J. López-parages, L. Blanquer, B. Rodríguez-fonseca, M. Lenton, Vasilis Dakos, et al.

\section{To cite this version:}

J. Carnicer, C. Domingo-marimon, M. Ninyerola, J. Camarero, A. Bastos, et al.. Regime shifts of Mediterranean forest carbon uptake and reduced resilience driven by multidecadal ocean surface temperatures. Global Change Biology, 2019, 25 (8), pp.2825-2840. 10.1111/gcb.14664 . hal-02194987

\section{HAL Id: hal-02194987 \\ https://hal.science/hal-02194987}

Submitted on 14 Dec 2020

HAL is a multi-disciplinary open access archive for the deposit and dissemination of scientific research documents, whether they are published or not. The documents may come from teaching and research institutions in France or abroad, or from public or private research centers.
L'archive ouverte pluridisciplinaire HAL, est destinée au dépôt et à la diffusion de documents scientifiques de niveau recherche, publiés ou non, émanant des établissements d'enseignement et de recherche français ou étrangers, des laboratoires publics ou privés. 


\title{
Regime shifts of Mediterranean forest carbon uptake and reduced resilience driven by multidecadal ocean surface temperatures
}

\author{
J. Carnicer ${ }^{1,2,3^{*+}}$, C. Domingo-Marimon ${ }^{2,4^{+}}$, M. Ninyerola ${ }^{5}$, J. J. Camarero ${ }^{6}$, A. Bastos ${ }^{7,8}$, J. \\ López-Parages $^{9}$, L. Blanquer ${ }^{1,2}$, B. Rodríguez-Fonseca ${ }^{9}$, T. M. Lenton ${ }^{10}$, V. Dakos ${ }^{11}$, M. \\ Ribas $^{1}$, E. Gutiérrez ${ }^{1}$, J. Peñuelas ${ }^{2,12}$, X. Pons ${ }^{4}$ \\ ${ }^{1}$ BEECA, Department of Evolutionary Biology, Ecology and Environmental Sciences. \\ University of Barcelona, 08028 Barcelona, Catalonia, Spain. \\ ${ }^{2}$ CREAF, Cerdanyola del Vallès, 08193 Barcelona, Spain. \\ ${ }^{3}$ GELIFES, Groningen Institute for Evolutionary Life Sciences, 9747 AG Groningen, The \\ Netherlands.
}

${ }^{4}$ Department of Geography, Grumets Research Group, Universitat Autònoma de Barcelona, 08193 Bellaterra, Catalonia, Spain.

${ }^{5}$ Department of Animal Biology, Plant Biology and Ecology, Grumets Research Group, Universitat Autònoma de Barcelona, 08193 Bellaterra, Catalonia, Spain.

${ }^{6}$ Instituto Pirenaico de Ecología (IPE-CSIC), 50192 Zaragoza, Spain.

7Laboratoire des Sciences du Climat et de l'Environnement, LSCE/IPSL, CEA-CNRS-

UVSQ, Université Paris-Saclay, F-91191 Gif-sur-Yvette, France.

${ }^{8}$ Ludwig-Maximilians-Universität Munchen, Dept. Of Geography, 80333 München,

This article has been accepted for publication and undergone full peer review but has not been through the copyediting, typesetting, pagination and proofreading process, which may lead to differences between this version and the Version of Record. Please cite this article as doi: $10.1111 /$ gcb. 14664

This article is protected by copyright. All rights reserved. 
Germany

${ }^{9}$ Complutense University of Madrid, UCM, Spain

${ }^{10}$ Earth System Science group, College of Life and Environmental Sciences, University of Exeter, Exeter EX4 4QE, UK.

${ }^{11}$ Institut des Sciences de I'Evolution, UMR 5554, CNRS, Université de Montpellier, CC 065, Place Eugéne Bataillon, 34095 Montpellier Cedex 05, France.

${ }^{12}$ CSIC, Global Ecology Unit, CREAF-CSIC-UAB, Cerdanyola del Vallès, 08193 Barcelona, Catalonia, Spain.

*Corresponding author: Jofre.Carnicer@ub.edu

${ }^{\dagger}$ These authors contributed equally to this work.

\begin{abstract}
The mechanisms translating global circulation changes into rapid abrupt shifts in forest carbon capture in semi-arid biomes remain poorly understood. Here we report unprecedented multidecadal shifts in forest carbon uptake in semi-arid Mediterranean pine forests in Spain over 1950-2012. The averaged carbon sink reduction varies between $31-37 \%$, and reaches values in the range of $50 \%$ in the most affected forest stands. Regime shifts in forest carbon uptake are associated with climatic early warning signals, decreased forest regional synchrony, and reduced long-term carbon sink resilience. We identify the mechanisms linked to ocean multidecadal variability that shape regime shifts in carbon capture. Firstly, we show that low frequency variations of
\end{abstract}

This article is protected by copyright. All rights reserved. 
the surface temperature of the Atlantic Ocean induce shifts in the non-stationary effects of El Niño Southern Oscillation (ENSO) on regional forest carbon capture. Modelling evidence supports that the non-stationary effects of ENSO can be propagated from tropical areas to semi-arid Mediterranean biomes through atmospheric wave trains. Secondly, decadal changes of the Atlantic Multidecadal Oscillation (AMO) significantly alter sea-air heat exchanges, modifying in turn ocean vapour transport over land and land surface temperatures, and promoting sustained drought conditions in spring and summer that reduce forest carbon uptake. Thirdly, we show that lagged effects of AMO on the winter North Atlantic Oscillation (NAO) also contribute to the maintenance of long-term droughts. Finally, we show that the reported strong, negative effects of ocean surface temperature (AMO) on forest carbon uptake in the last decades are unprecedented over the last 150 years. Our results provide new, unreported explanations for carbon uptake shifts in these drought-prone forests and review the expected impacts of global warming on the profiled mechanisms.

\section{Introduction}

The quest to identify the diverse mechanisms driving abrupt shifts in the dynamics of climate affecting ecosystems has gained considerable scientific attention in recent decades (Lenton et al. 2008, Scheffer et al. 2009). Numerous empirical studies have reported abrupt regime shifts between contrasting persistent states of these ecosystems (Scheffer et al. 2009, Chen \& Tung 2014). Several natural phenomena have been long identified as key drivers of rapid changes in the state of terrestrial ecosystems and in their carbon sink capacity, including changes in regional climate regimes. Multidecadal fluctuations in sea surface temperatures (SST), quantified by ocean variability indices (e.g. the Atlantic Multidecadal Oscillation (AMO), and the Pacific Decadal Oscillation

This article is protected by copyright. All rights reserved. 
(PDO)), are important drivers of long-term changes in the trends of rainfall in tropical, semi-arid and extratropical areas of the globe (McCabe et al. 2004, Sutton \& Hodson 2005). Rapid shifts in SST can affect multiple ocean basins, forcing regime shifts in global atmospheric circulation patterns (Quan et al. 2004, Wang et al. 2013). Changes in SSTs also control inter-annual variability in the global terrestrial sink, through the propagation of temperature and rainfall anomalies (Bastos et al. 2013, Poulter et al. 2014, Kim et al. 2017). However, the precise mechanisms connecting major changes in the thermal state of ocean basins and the carbon sink dynamics of forest ecosystems remain yet poorly understood. For example, we lack comprehensive descriptions of the multiple mechanisms linking long-term carbon sequestration by forests to multidecadal shifts in SSTs. Similarly, it has not been assessed whether transitions between the warm and cold ocean phases result in abrupt or gradual shifts in forest carbon uptake regimes, whether and how these shifts vary geographically and the diverse climatic mechanisms implied.

Recent research indicates that semi-arid forests are key determinants of the variability in the carbon sink capacity of terrestrial ecosystems (Poulter et al. 2014). Semi-arid and dryland systems cover $45 \%$ of the Earth's land surface, and recent assessments assert that over the last decades are becoming an increasingly important driver of the terrestrial carbon sink capacity of the Earth at interannual time scales (Poulter et al. 2014, Ahlström et al. 2015). These biomes are distributed at the transitional edge between desert and temperate regions of the biosphere, and as a result their carbon sink activity could be severely disrupted during the next decades by global warming and the ongoing latitudinal expansion of the Hadley cells (Fu 2015, Lau \& Kim 2015). In addition, global warming may possibly induce an increased frequency and severity of eastward propagating extreme El Niño events, and impact drought regimes in key semi-

This article is protected by copyright. All rights reserved. 
arid areas (Cai et al. 2015).

Here we examine the occurrence of regime shifts in forest carbon uptake in the dominant dry coniferous forests of the Western Mediterranean Basin (Aleppo pine, Pinus halepensis Mill.), located in continental Spain. Detailed empirical descriptions of regime shifts in forest carbon uptake are currently lacking in this semi-arid region. Next, we provide empirical evidence for several mechanisms driving regime shifts in forest carbon uptake. The first mechanism examined is the operation of large-scale, non-stationary effects of El Niño Southern Oscillation (ENSO) events that are propagated from tropical to extratropical areas through atmospheric wave trains (López-Parages \& Rodríguez-Fonseca 2012, López-Parages et al. 2015, 2016). The ENSO is the strongest year-to-year climate fluctuation of the planet and it is tightly linked to interannual variations in carbon sink capacity of terrestrial ecosystems (Hashimoto et al. 2004). The propagation of the ENSO signal from tropical to extratropical areas can be strongly modulated by ocean multidecadal variability and this has not been considered in the analysis of forest carbon uptake regime shifts. To address this gap here we analyse how the interactions between the ENSO and the Atlantic Ocean Multidecadal Oscillation (AMO) could jointly drive regime shifts in forest carbon uptake. The second mechanism examines the effects of ocean multidecadal variability in SST on long-term trends of sea-air heat exchange, water vapour transport over land, sea level pressure and land temperature conditions. Changes in these climatic variables linked to ocean multidecadal states can induce sustained drought conditions over land and limit the carbon sink capacity of forests. Thirdly, we analyse whether lagged multidecadal variability in major atmospheric modes such as the North Atlantic Oscillation (NAO) significantly affects long-term drought events. The positive phase of AMO results in more frequent negative NAO events and blocking 
episodes associated to extreme climate events (Häkkinen et al. 2011, Peings \& Magnusdottir 2014). Moreover, lagged multidecadal links between AMO and NAO have been extensively documented, and may influence drought events and therefore forest ability to uptake carbon (Peings \& Magnusdottir 2014, Li et al. 2013).

To summarise, here we address the following research objectives: $i$ ) to provide a first description of coupled shifts in drought regimes and carbon uptake in semi-arid Aleppo pine forests in Spain, using combined climatic and dendrochronological time-series analyses spanning the last six decades (1950-2012); ii) to characterize the observed regime shifts using diverse statistical techniques including early-warning signal analyses; iii) to identify the teleconnections significantly associated with the reported regime shifts, quantifying the associated changes in the patterns of ocean water vapour transport over land, land temperature and sea level pressure; $i v)$ to test whether the nonstationary effects of ENSO mediated by ocean multidecadal variability determine the onset of regime shifts of forest carbon uptake; and $v$ ) to provide a unified framework for all the examined mechanisms, summarising the expected effects of global warming on the studied processes.

\section{Materials and Methods}

\section{Climatic and forest data}

The study area comprised the Spanish Iberian Peninsula and it was subdivided into grids of $280 \times 280,140 \times 140$, and $70 \times 70 \mathrm{~km}^{2}$ (Supplementary Fig. 1). Climatic data were obtained from the State Meteorology Agency (AEMET) during 1950-2012. We used the Standardised Precipitation Evapotranspiration Index (SPEI) to quantify droughts (Vicente-Serrano et al. 2010). A spatially averaged value of monthly SPEI was

This article is protected by copyright. All rights reserved. 
calculated for each grid cell during the 1950-2012 period. The resulting data set was structured in a pool of 5191 SPEI grids, covering different time scales $(3,6,9,12,18$, 24, and 36 months; Domingo-Marimón 2016). Monthly values of sea-level pressure (SLP), water vapor transport and temperature fields between 1950 to 2010 at 1 degree resolution were derived from ERA-20C Reanalysis (Poli et al. 2016). The yearly variation in gain of carbon stocks was quantified in a network of 20 Aleppo pine forests (Pinus halepensis Mill.) (Supplementary Fig. 1). Dendrochronological analyses and allometric equations were applied to calculate the variation in carbon stocks linked to tree growth in each of the forest stands for 1950-2012 $\left(\mathrm{kg} \mathrm{ha}^{-1} \mathrm{y}^{-1}\right.$, Forest net carbon uptake hereafter $[F C U]$, Montero et al. 2005). Note that this variable does not account for tree and soil respiration fluxes and therefore provides a proxy of the net primary productivity specifically linked to tree growth (Montero et al. 2005). Tree density and stand basal area were measured in each stand (Ribas, 2006, Camarero et al. 2015a). A variable number of trees (8-38) were randomly sampled for dendrochronological analyses in an area of 2 ha (Ribas, 2006). The selected trees were located at least 5-10 m apart. We extracted 2-4 radial cores per tree at $1.3 \mathrm{~m}$ using a Pressler increment borer. Wood samples were sanded and visually cross-dated. Tree-ring widths were measured to the nearest $0.01 \mathrm{~mm}$ using a LINTAB measuring device (F. Rinntech, Germany), a binocular scope, and the programmes CATRAS and TSAP. The COFECHA software was used to assess the accuracy of the visually cross-dated samples. For each tree, we also measured the diameter at breast height (DBH, measured at $1.3 \mathrm{~m}$ ), the stem height and the bark thickness to calculate the annual increase in basal area.

This article is protected by copyright. All rights reserved. 


\section{Description of regime shifts}

We first assessed the existence of unreported abrupt shifts in drought regimes and forest carbon uptake, analysing the time series of drought trends and dendrochronology data in the Iberian Peninsula (objective i). The SPEI allowed us to explore shifts in drought regimes at temporal scales ranging from 3 to 36 months during 1950-2012. SPEI and dendrochronological time series were analyzed applying spline fits (SAS Institute 2012). To assess the effects of abrupt shifts in the drought regime on forest carbon storage, we subsequently examined the yearly increase in carbon stock in a large-scale network of 20 Aleppo pine forests during 1950-2012 (Supplementary Figure 1). This tree species was selected because it is the dominant native conifer in the eastern Iberian Peninsula and in the driest areas of the Western Mediterranean Basin. The selected stands represented the native geographical distribution of this taxon across the Iberian Peninsula, providing a regional assessment for this species (Supplementary Fig. 1). Regression tree analyses were applied to detect abrupt shifts in time series (De'ath \& Fabricius 2000). We identified an optimal splitting point (i.e. time of shift) in the time series separating multiannual periods characterized by contrasting values in the analysed variable. The magnitude of the shift between two periods was quantified by the amount of the variance explained by the model and was therefore inversely proportional to the model-corrected Akaike Information Criterion (1/AICc). The splitting criterion was based on the LogWorth statistic (SAS Institute 2012). When a significant shift was detected in the regression tree and spline analyses, we applied a Tukey-Kramer analysis to test for significant differences in values between the two multiannual periods before and after the splitting point. For all forest stands, we computed the resistance, recovery and resilience indices for tree growth and analysed their trends (LLoret et al. 2011, Gazol et al. 2018). In addition, these indices were 
subsequently modified in a second step to more properly describe decadal trends. We computed the following indices of forest resilience (FCUR) and recovery capacity after a regime shift (FCURC), defined as follows:

$$
F C U R=\frac{\bar{X}_{F C U \text { BEFORE }(5 \text { years })}}{\bar{X}_{\text {FCU AFTER }(t \text { years })}}
$$

where $\bar{X}_{\mathrm{FCU}}$ is the averaged forest net carbon uptake $\left(\mathrm{kg} \mathrm{ha}^{-1} \mathrm{y}^{-1}\right)$ over a 5 year period before the regime shift in the numerator and over a variable number years after the regime shift in the denominator ( $t$, ranging from 1 to 30 years). The recovery capacity after a regime shift was computed as follows:

$$
F C U R C=\frac{F C U_{\text {AFTER (year of the shift) }}}{\bar{X}_{F C U \text { AFTER (3 year rolling window) }}}-1
$$

Finally, following previous works (Camarero et al. 2015a) we also computed a synchronicity index, measured as the averaged Pearson $r$ coefficient between the forests stands.

\section{Early-warning signal analyses}

To characterise early-warning signals associated to the observed regime shifts, earlywarning signals were quantified using the earlywarnings R package (Dakos et al. 2012) using climatic data (objective ii). The analyses were restricted to the time period before the splitting point previously identified by the regression tree models. The functions generic_ews and qda_ews were used to estimate the following eight statistical moments within rolling windows along the time series: the autoregressive coefficient $[\operatorname{ar}(1)]$ of a first-order AR model fitted to the data, the standard deviation, skewness, kurtosis, the

This article is protected by copyright. All rights reserved. 
coefficient of variation, the return rate of the data estimated as the 1-ar(1) coefficient, the density ratio of the power spectrum of the data estimated as the ratio of low to high frequencies, and the autocorrelation at the first lag of the data (Supplementary Table 1). The trends of these eight statistical moments were estimated by using the nonparametric Kendall tau correlation coefficient. The function sensitivity_ews was applied to plot the Kendall tau estimates and their $p$-values for the range of rolling-window sizes used, together with a histogram of the distributions of the statistic and its significance. The analyses were computed for a large range of window sizes (winsize parameter: 10, $20, \ldots 50)$. We computed and plotted the power spectrum estimated by the spec.ar function for all frequencies within each rolling window. Positive feedback processes originating non-linear responses and early warning signals may occur in both climatic and ecological processes (Supplementary Fig. 2). Consequently, early-warning signals were assessed for climatic and forest variables (SPEI 3-12; FCU variables) and contrasted applying Tukey-Kramer tests.

\section{Teleconnection analyses}

To analyse the effects of teleconnections on drought and carbon uptake regime shifts (objective iii), we gathered data for the following teleconnection indices: the AMO, the Multivariate ENSO index (MEI), the North Atlantic Oscillation index (NAO), the Western Mediterranean Oscillation index (WeMOI), and the Arctic Oscillation (AO) index, the Pacific Decadal Oscillation (PDO) and the Eastern Atlantic Pattern (EA) (see supplementary materials for further details on data sources). Structural equation models (SEM) were applied to assess the relative influence of teleconnection indices on SPEI variability (objective iii) (R Development Core Team 2017). Alternative SEM models were compared and selected minimizing the AIC and the Bayesian Information 
Criterion (BIC). The basic SEM model scheme selected is outlined in Supplementary Fig. 3. SEM models were complemented with multiple regression analyses (based on Ordinary Least Squares, OLS). Linear regression analyses of teleconnection indices were performed for SLP, water vapor transport, SPEI and mean air surface temperature to map the effects of teleconnection indices on atmospheric circulation patterns. Wavelet coherence analyses allowed the detection of similar periodicities in the fluctuations of teleconnection and SPEI time series and the estimation of their phase differences.

Regime shifts and non-stationary interactions between ENSO and AMO

We hypothesized that the multidecadal variation of the Atlantic SST measured by the AMO could trigger regime shifts in drought and, as a consequence, in net forest carbon capture linked to tree growth (FCU). The proposed mechanism is the operation of non-stationary effects of higher frequency teleconnection patterns (e.g. ENSO and other teleconnection indices) modulated by ocean multidecadal variation (López-Parages \& Rodríguez-Fonseca 2012, López-Parages et al. 2015, 2016). To assess whether non-stationary effects of ENSO mediated by ocean multidecadal variability (AMO) were determining the onset of regime shifts in drought and carbon uptake trends (objective iv) we tested two diagnostic predictions. Firstly, we documented the occurrence of spatiotemporal shifts in the non-stationary effects of MEI on drought (SPEI) (Prediction 1, P1). To test this prediction, we performed multiple regression modelling analyses (ordinary least squares, OLS) for subsets of consecutive 10-year time windows for each grid cell in the study region, allowing the detection and

This article is protected by copyright. All rights reserved. 
mapping of non-stationary effects of ENSO. Complementarily, we also assessed the non-stationary effects observed for other teleconnections characterised by high frequency, interannual variability modes (NAO, WeMOI, EA, AO). Significant multiple regression estimates of the OLS models were subsequently mapped for each decade allowing the detection of spatial and temporal shifts in the effects of ENSO, NAO and high-frequency teleconnections on SPEI. Secondly, we analyzed whether rapid changes in the AMO during the regime shift period significantly predicted the changes in the non-stationary effects of the Multivariate ENSO index on net forest carbon capture associated with tree growth $(F C U)$ (Prediction 2, P2). To assess this prediction, we performed rolling correlation analyses between forest carbon uptake (FCU, $\mathrm{kg} \mathrm{ha}^{-1}$ $\mathrm{y}^{-1}$ ) and the MEI index [rFCU-MEI correlation coefficients hereafter]. Rolling correlation analyses were calculated for each forest stand using the rollaplyr function in the package zoo (R Development Core Team 2017), obtaining the Pearson correlation coefficient in the cor function (stats package) and running the analyses for varying window width parameters $(10,15,20,25$ years). The analyses of $r F C U-M E I$ correlation coefficients were conducted for annual and monthly values of MEI. Furthermore, we analysed whether the AMO was significantly associated with the variation observed in the $r F C U-M E I$ correlation coefficients. During regime shifts, we expected the observation of significantly negative relationships linking rFCU-MEI values and the AMO index, due to increased negative effects of ENSO on forest carbon uptake associated with a warmer AMO state.

This article is protected by copyright. All rights reserved. 
Testing for amplified effects of AMO during the last 150 years

To analyse whether the reported negative effects of AMO on forest carbon uptake detected in 1950-2012 were unprecedented during the last 150 years, we extended the analyses to the 1850-2012 time period. We applied ordinary squares multiple regression models (OLS) analysing the effects of teleconnection indices on forest carbon uptake. The OLS models contrasted the observed effects of AMO on forest carbon capture for different consecutive time periods over the 1850-2012 series, and were repeated at different time period resolutions (decadal, bidecadal, 30 years [corresponding to AMO positive and negative periods], 60 years). For the 60 -year resolution, we computed the observed AMO effects in the IPCC-AR5 reference period (1850-1899, P1) and in two subsequent time periods (P2: 1900-1959 and P3: 19602012). Changes in the starting year of the analysed multidecadal periods did not qualitatively change the reported results. Results for decadal and bidecadal resolution are not shown.

\section{Testing complementary hypotheses}

Forest carbon uptake trends can be significantly affected by stand structure and past management practices (Pan et al. 2011, Coomes et al. 2014), by tree age, height and ontogenetic stage (Camarero et al. 2015b) and by the increase of post-industrial atmospheric $\mathrm{CO}_{2}$ concentrations (Camarero et al. 2015b, Keenan et al. 2016). To assess the effects of these complementary processes on the reported trends of forest carbon uptake the following variables were quantified: stand tree density, stand mean

This article is protected by copyright. All rights reserved. 
diameter at breast height, stand mean tree height, the age of the sampled trees, and the annual increase of atmospheric concentrations of $\mathrm{CO}_{2}$ (see supplementary Table S2 for a detailed description). Following the methods proposed in previous works (Camarero et al. 2015b), we extracted the residual variation of forest carbon uptake not linked forest structure and age $\left(\operatorname{res} C_{i n c r}\right)$. Subsequently, we tested whether this remaining variation was significantly associated to the examined teleconnections (AMO, MEI, AO, WeMOI, NAO) and to the variation of post-industrial atmospheric $\mathrm{CO}_{2}$ applying multiple regression OLS analyses.

\section{Results}

Drought and forest carbon uptake regime shifts (objective i)

Regression tree analyses identified a consistent shift in SPEI trends affecting the entire central-eastern Iberian Peninsula in 1980-1981 (Fig. 1). This abrupt shift was characterised by drier conditions from the 1980s onwards, and it was consistently detected in regression tree models across a wide range of SPEI temporal scales (3-36 months) and across different scales of spatial grids (Supplementary Figs. 4-8). Average SPEI values consistently differed before (1950-1979) and after the abrupt shift (Supplementary Fig. 9a, Tukey-Kramer test p<0.0001). A different pattern of longitudinal variation of average SPEI values was observed before and after the 19801981 shift - with the SPEI switching from increasing with longitude to decreasing with longitude, i.e. climate conditions were drier eastwards (towards the Mediterranean coast) after the shift (Supplementary Fig. 9b).

This article is protected by copyright. All rights reserved. 
As found for SPEI, the trends in carbon stocks clearly shifted in 1980-1981 in 18 of the 20 forests, changing from sustained positive gains to stable, non-significant trends (Fig. 2a, Supplementary Figs. 10-12). The trends in two cases reversed from significantly positive to significantly negative (Fig. 2a). Regression tree models based on the changes in forest carbon uptake identified significant shifts in 16 of 18 stands during 1978-1981 (Supplementary Table 3), in line with the shift in drought dynamics (Fig. 1). Before the regime shift, we observed a progressive significant increase in forest carbon uptake synchrony (Fig $2 b$, cubic polynomial fit, $\mathrm{p}<0.0001$ ), followed by a significant reduction after the shift $(\mathrm{p}<0.0001$, Supplementary Figure S13). For the whole period after the regime shift, synchrony values remained significantly lower relative to $1950-79$ (T-K test, $\mathrm{p}<0.0001)$ and there was an increase of non-significant values (Supplementary Fig. S13). In a similar manner, the forest carbon uptake resilience index (FCUR) indicated a sustained reduction $(31-37 \%)$ of the forest sink after the regime shift (Fig 2b, see Supplementary Table 4 for further details). Forests were also characterised by a limited recovery capacity, with most stands showing recovery rates of $10-17 \%$ respect to the minimum FCU level observed after the drought regime shift (Fig 2c, Supplementary table 5). In summary, all the results indicated a coherent abrupt large-scale shift in forest carbon uptake trends in this area and allowed testing for alternative large-scale drivers of these trends.

\section{Early-warning signal analyses (objective ii)}

Having identified abrupt shifts in forest and drought regimes, we examined whether they carried any early-warning signals. We assessed this by estimating changes in lag-1 autocorrelation in the time series before the regime shift (Dakos et al., 2012, Camarero et al., 2015a). Abrupt shifts in drought regime in the eastern Iberian Peninsula were 
preceded by an increase in autocorrelation only in SPEI (Fig 3a, Supplementary Fig. 14). In contrast, non-significant AR-1 values were observed in FCU time series before the shift (Fig 3a). In line with these findings, SPEI AR-1 and the Kendall tau statistic quantifying autocorrelation trends were positively associated with the magnitude of the regime shift in the local SPEI time series (Fig. 3b, c). In other words, sites experiencing more abrupt shifts in SPEI values in 1980 (i.e. presenting higher values of $R^{2}$ and 1/AIC in regression tree models) showed significantly higher Kendall tau and AR-1 values before the regime shift (i.e. in 1970-79). Overall, all the early-warning results indicated a major role of climatic variables as putative drivers of the reported shifts, highlighting the need of detailed analyses of teleconnections and climatic variables.

\section{Teleconnections associated with the reported regime shifts (objective iii)}

The models identified AMO as the strongest predictor of the variability in SPEI values (Fig. 3d, Supplementary Fig. 15, and Supplementary Table 6). Furthermore, the standardised coefficients of AMO on SPEI were robust predictors of the magnitude of the regime shift detected by the regression tree models in each grid cell (Fig. 3e). In addition, wavelet coherence analyses confirmed the observed significant links between the AMO index and the SPEI values, reporting significant associations at long time periods (>128 months) in cells characterised by strong shifts in drought regime (Supplementary Fig. 16). These results identified the AMO index as a significant predictor of the abrupt shifts in the drought regimes (Supplementary Table 6). Moreover, the values of the Kendall tau statistic quantifying autocorrelation trends were positively associated with the effect of the AMO on the drought indices (Fig. 3f). In the case of tree carbon sequestration models, we applied multiple regression OLS models and identified AMO as the best teleconnection index for predicting changes in 
carbon stocks in the Aleppo pine stands. The models revealed a significantly stronger AMO signal for carbon-stock gains in northern stands (Supplementary Table 7).

In order to understand the physical processes driving the correlations found, we applied regression analyses mapping the effects of AMO on ocean and land water vapour transport, sea level pressure, ocean surface temperature and land mean air temperature (Supplementary Fig. 17, see Methods). Positive AMO states were significantly associated with increased drought conditions across the Iberian Peninsula, spanning from January to October (Supplementary Fig. 17). Furthermore, analyses of the seasonal variation of SPEI after the regime shift reported a significant increase of drought impacts in the same seasonal time period (winter, spring and summer), which were in turn paralleled by a significant increase of AMO positive anomalies in spring and summer (Supplementary Fig. 18). Thus, changes in the annual dynamics of AMO and SPEI largely impacted the growing season of forests.

Regime shifts and non-stationary interactions between ENSO and AMO (objective iv)

The results suggested a key role of non-stationary effects of ENSO modulated by AMO and supported the two diagnostic predictions $(P 1$ and $P 2)$. Firstly, multiple regression OLS models for the SPEI drought index for subsets of consecutive 10-year time windows allowed the detection of non-stationary effects of higher frequency teleconnections. The models detected changes in the non-stationary effects of the El Niño Southern Oscillation (MEI), promoting autumn rains in the 1970s and increased spring and summer drought conditions during the start of the regime shift, in the 1980s (Fig. 4a), being the former more marked in the south and western part of the Iberian Peninsula and the latter in the south and eastern part. Crucially, the spatial shifts in the effects of the models in the 1980s closely matched the spatial pattern reported for the drought patterns (Fig. 1). The models also highlighted a key role of non-stationary

This article is protected by copyright. All rights reserved. 
effects of positive winter NAO phases (December, January) in the 1990s, showing a multidecadal pattern (Fig 4b). Of note, the NAO signal was significantly correlated with lagged $\mathrm{AMO}$, and this correlation was maximised at a lag of 15 years $\left(R^{2}=0.16\right.$; $p=0.0048$ ), as reported in previous works ( $\mathrm{Li}$ et al. 2013). In addition, we examined whether AMO was a significant predictor of the correlations between forest carbon uptake and ENSO ( $r F C U-M E I$ correlations) during the onset of the regime shift period (1980s). As predicted, in the 1980s we observed a significantly negative $r F C U-M E I /$ AMO relationship in the stands affected by regime shifts (Fig. 5a). A shift to a warmer state of the AMO index in the 1980s was consistently associated to more negative Pearson correlation values, and the observed negative relationships were mostly significant from March to October (Fig. 5b-c). The analyses covering the 1850-2012 period reported that the strong, negative effects of AMO in the 1980s were unprecedented over the last $~ 150$ years (Supplementary Fig. S19, and Supplementary Table 8). While previous negative AMO phases [e.g. 1897-1930] were significantly associated to increased forest carbon uptake levels in the OLS models (Supplementary Table 8), strong linear effects of AMO were only detected in the regime shift period (i.e. in the 1980s [1963-1996 negative AMO phase], see Supplementary Fig. S19).

\section{Effects of forest stand structure, tree age and atmospheric $\mathrm{CO}_{2}$}

We observed that forest tree density, mean stand tree height and tree age explained a significant fraction of forest carbon uptake variation across sites $\left(R^{2}=0.27 ; p<0.0001\right.$, Supplementary Table 10). OLS models examining the residual variation after accounting for stand structure and tree age effects indicated that the reported effects of AMO were robust (Supplementary Table 11). Similarly, the results indicated a significant but small effect of increased atmospheric $\mathrm{CO}_{2}$ concentrations on forest

This article is protected by copyright. All rights reserved. 
carbon uptake, which co-acted with significant negative effects of AMO

(Supplementary Table 12).

\section{Discussion}

Our results describe previously unreported regime shifts in drought and carbon uptake across Iberian Aleppo pine forests (Figs. 1-2), and identify the climatic drivers implied (Figs. 3-6). This tree species is the most dominant conifer in semi-arid or dry lowland areas of the Western Mediterranean Basin and therefore it is of major ecological relevance in such drought-prone regions. The reported drought regime shifts strongly affect forest carbon uptake of these forests, showing a sustained multidecadal reduction of carbon sequestration. The averaged carbon sink reduction for all stands varies between $31-37 \%$, but reaches values in the range of $50 \%$ in the most affected stands (Fig 2b). SEM analyses indicated that AMO is the key regulator of the observed trends, being in turn significantly associated to early warning indicators. The results indicate that AMO acts as a key modulator of different non-stationary mechanisms over analysed drought regime shift period. We suggest that the mechanisms operate sequentially, following this order: 1) the modulation by AMO of the effects of ENSO on drought and forest carbon uptake, acting over the 1970s-1980s (e.g. Figs. 4 and 5), which is a key mechanism because it determines the onset of the regime shift period; 2) a sustained negative effect of positive AMO phases on ocean moisture advection and water transport at the multidecadal scale, acting over the 1980s-2000s, and linked to a significant increase on spring and summer temperatures (Supplementary Fig. 17); and, lastly, 3) the lagged multidecadal variation of the NAO (relative to the AMO) that significantly affects drought indices in the 1990s. A synthetic diagram summarising these three mechanisms is provided in Fig. 6.

This article is protected by copyright. All rights reserved. 
Referring to the first mechanism, our results support that non-stationary interactions between ocean multidecadal variability (AMO) and the ENSO determine the onset of abrupt shifts in forest carbon capture in the studied semi-arid forests. We propose that these non-stationary effects of ENSO in extratropical areas could be possibly linked to modified Rossby wave train activity (López-Parages \& Rodríguez-Fonseca 2012, López-Parages et al. 2015, 2016) (e.g. Supplementary Fig. 20). The abrupt, non-linear regime shift observed in the 1980s and its significant association with both AMO and ENSO suggest a key role for non-linear atmospheric responses specifically linked to the patterns of sea surface temperature (SST) associated with ENSO and AMO. Below, we review in detail the fundamental processes that may shape this mechanism.

It is well known that AMO and ENSO describe large-scale patterns of SST and therefore influence air-sea heat exchanges. Increases in SST induce a net transfer of heat from the sea to the atmosphere and result in diabatic heating of the lower atmosphere (Bjerknes 1964, Gulev et al. 2013). Through these diabatic processes SST can in turn influence ocean-land advection and zonal winds, as well as the dynamics of the Walker and Hadley circulation cells (Wang 2002, Sutton and Dong 2012). All these fundamental air-sea exchanges may upscale affecting large geographic regions, modifying in this way atmospheric circulation dynamics and Rossby wave train dynamics, and shifting the geographic location of anticyclones and lows (Cassou et al. 2005, López-Parages \& Rodríguez-Fonseca 2012, Mariotti et al. 2012, López-Parages et al. 2015, 2016, Sun et al. 2017).

Previous works have shown that above determinate threshold values of SSTs non-linear trends in atmospheric responses and rainfall patterns have been consistently observed (Quan et al. 2004, Power et al. 2006, López-Parages et al. 2016). Crucially, the 
available evidence supports that atmospheric Rossby wave trains can respond nonlinearly to changes in ocean thermal state (SST) and to ENSO events (Hoerling et al. 2001, López-Parages et al. 2016). In other words, non-linear atmospheric effects linked to increased SST can shape Rossby wave train activity connecting major ocean basins and strongly affect rainfall trends in extratropical areas as the Iberian Peninsula (LópezParages et al. 2016). More precisely, ENSO events typically generate a Tropical Northern Atlantic pattern (TNA) and induce two separate atmospheric wavetrains (centered respectively on the Pacific and Atlantic Oceans) (López-Parages et al. 2016, Rodríguez-Fonseca et al. 2016). Notably, in the case of ENSO events, the response to rainfall, sea level pressure and wind is often more linear in the tropics but can be strongly non-linear in the extratropics (Frauen et al. 2014).

Recent works have applied atmospheric circulation models to explicitly simulate the interactions between ENSO events and ocean multidecadal thermal state (Frauen et al 2014, López-Parages et al. 2016). These works have implemented numerical experiments in models forced by idealized ENSO-AMO patterns (López-Parages et al. 2016). The resulting simulations indicate that AMO and ENSO can jointly modulate the patterns of atmospheric Rossby wave trains, and significantly alter extratropical drought responses (Supplementary Fig. 20). Under negative AMO phases (i.e. during the 1970s), the model simulations and observational data indicate enhanced Rossby wave train activity linked to a weakened jet in zones characterised by negative meridional thermal gradients (López-Parages et al 2015, Rodríguez-Fonseca et al. 2016). Under negative AMO phases (i.e. during the 1970s), the model simulations and the observational data indicate enhanced Rossby wave train activity triggered by ENSO over the North Atlantic sector. This fact is related to a weakened jet in zones characterised by negative thermal gradients (López-Parages et al. 2015, Rodríguez-

This article is protected by copyright. All rights reserved. 
Fonseca et al. 2016). Thus, under cold North Atlantic SST conditions, the models indicate an enhanced wave activity triggered by ENSO and connecting the Pacific basin and the Atlantic European region (Supplementary Fig. 20). In these conditions, the ENSO-related wave activity flux $\left(\mathrm{m}^{2} / \mathrm{s}^{2}\right)$ crossing the North Atlantic at upper troposphere $(200 \mathrm{hPa})$ triggers in turn a deep low-pressure system over the British Islands, producing significantly increased rains in Northern Europe and significantly increased drought conditions in semi-arid Mediterranean areas (López-Parages et al. 2015, 2016). Overall, the available modelling evidence and the observational results (Figs. 4 and 5, Supplementary Fig. 20) suggest an important role for modified Rossby wave trains associated with multidecadal ENSO-AMO variability, potentially effecting drought and forest carbon regime shifts.

The results indicate that $\mathrm{AMO}$ has a large influence on long-term multidecadal drought and carbon uptake dynamics. AMO is significantly associated with increased spring and summer drought conditions at the multidecadal scale, affecting land temperatures, water vapour transport over land and standardised drought indicators (SPEI) (Supplementary Fig. 17). The observed effects of AMO on the climatic variables are mainly concentrated in the March-October period (Supplementary Figs. 17-18). These results add to previous studies documenting a pervasive influence of AMO on several components of the climatic system (reviewed in Supplementary Box 1a). Beyond the effects of AMO and SSTs on atmospheric Rossby wave train dynamics, diabatic processes linked to increased SSTs have multifaceted effects and influence multiple atmospheric phenomena. These effects are reviewed in Supplementary Box 1b and include the alteration of the Hadley and Walker cell size, shape and dynamics, the location and seasonal migration of the intertropical convergence zone (ICTZ) and the

This article is protected by copyright. All rights reserved. 
tropical monsoon activity and its links to mid-latitude zones. The reviewed evidence supports that these co-acting processes may also strongly impact drought regimes.

A remaining question is how these mechanisms might be currently affected by ongoing global warming and how they might evolve in the near future (see Supplementary Box 1c for a detailed discussion). The AMO is linked to the Atlantic multidecadal overturning thermohaline circulation (AMOC), which in turn currently stands as a major modulator of the responses of the earth system to global warming (Chen \& Tung 2014, Hansen et al. 2016, Sgubin et al. 2017, Caesar et al. 2018, Thornalley et al 2018). Moreover, global warming may strongly interact with AMO in present day conditions and in future scenarios. For example, amplified ocean multidecadal oscillations have been reported in the last decades and related to global warming (Moore et al. 2017). These amplified oscillations suggest a scenario in which global warming progressively increases the amplitude of AMO cycles in the next decades (Supplementary Fig. 21a). In line with these trends, less frequent and longerlived oscillations have also been reported for the Pacific Decadal Oscillation (PDO), producing a deepening of the ocean mixed layer (Boulton \& Lenton 2015).

In addition, global warming could also be promoting a progressive slowdown of the AMOC (Supplementary Fig. 21b). In fact, an unprecedented reduced AMOC state has been recently also discussed, presumably linked to global warming and increased Greenland ice sheet loss (Bamber et al. 2012, Robson et al. 2014, Rahmstorf et al. 2015, Sgubin et al. 2017, Caesar et al. 2018, Thornalley et al. 2018). Besides, AMO and ENSO influence wildfire occurrence (Kitzberger et al. 2015). Therefore, amplified 
AMO, changes in ENSO dynamics and global warming could jointly affect fire frequency in the next decades and impact forest carbon sinks (Supplementary Fig. 21c). In addition, Arctic climate amplification processes significantly interact with ocean multidecadal phases. For example, recent works indicate that Arctic warming has been enhanced by the current phase (PDO-, AMO+), leading to a reduction of the poleward temperature gradient and to reduced westerlies (Screen \& Francis 2016, Tokinaga et al. 2017, Su et al. 2017). Additional modelling evidence has forecasted strong interactions between AMOC, AMO and global warming in the next decades (Hansen et al. 2016, Sgubin et al. 2017).

Global warming is also expected to impact Rossby wave trains (Supplementary Fig. 21d). A significant impact of Arctic amplification processes on atmospheric Rossby wave trains is expected (Francis \& Vavrus 2012, Coumou et al. 2015). Rising nearsurface air temperatures in the Arctic exceed mid latitude warming by a factor of at least two since the late 1990s (Francis et al. 2017). The amplification of Arctic temperatures by global warming typically promotes a reduced poleward temperature gradient and slower eastward progression of Rossby waves (i.e. weakened zonal winds and increased wave amplitude). Slower progression of waves in turn produces more persistent associated weather patterns in mid-latitudes, increasing the probability of extreme weather events (drought, flooding, cold spells, heat waves). ENSO dynamics might be also altered by global warming, possibly increasing the frequency and intensity of Eastward propagating ENSO events (Cai et al. 2015) (Supplementary Fig. 21e). Other works indicate that global warming may also promote more persistent La Niña conditions (Mann et al. 2009, McPhaden et al. 2015) (Supplementary Fig. 21f). For example, palaeoclimatic evidence from the Medieval Climate Anomaly suggests 
that increased radiative forcing can increase La Niña-like states (Mann et al. 2009, Marsicek et al. 2018). Global warming will also elevate tropical SSTs, which in turn will possibly induce a more elevated outflow of the rising branch of the Hadley cell, enhancing drought in semi-arid biomes at mid latitudes (Fu 2015, Lau \& Kim 2015) (Supplementary Fig. 21g). Under warmer SSTs, the raising air reaches a more elevated tropopause, becoming dehydrated by colder temperatures, and drier air is produced when subsidising at mid-latitudes in semi-arid regions (Fu 2015, Lau \& Kim 2015). Finally, global warming could progressively modify ocean-land interactions that intervene in the generation of drought periods and the advection of ocean humidity over land (Fu 2015, McPhaden 2015) (Supplementary Fig. 21h; Supplementary Box 2). In the context of increasing global warming, water vapor content over land may not increase fast enough relative to the rapid temperature warming, resulting in drier air masses in extensive continental areas of the globe (Sherwood \& Fu 2014, Fu 2015). The relative balance between Arctic and Antarctic amplification could also alter globally ocean heat transport by AMOC, SST patterns, and impact global drought patterns (Supplementary Fig. 21i).

Overall, there is robust evidence suggesting notable impacts of global warming on the major components analysed, including AMO, ENSO and atmospheric Rossby wave trains. Grey circles in Supplementary Fig. 21 synthesize the expected major impacts of global warming that could in turn affect regime shifts in drought and forest carbon uptake. The future dynamics of atmospheric Rossby wave trains and the associated drought regimes at mid-latitudes will depend on the relative strength of different global warming amplification processes at different latitudinal bands (Supplementary Fig. 21a-i). For example, the co-occurrence of arctic positive feedbacks and tropical Hadley 
cell amplification processes is expected. The relative strength of tropical, arctic and antarctic amplification processes, though, will ultimately shape the meridional temperature gradient at mid-latitudes, determining in this way long-term Rossby wave train dynamics, the frequency of blocking activity and drought regimes in semi-arid areas (Francis et al. 2017). Due to the strong links and interactions reported for all the components reviewed, a wide range of possible scenarios should be considered.

Our results are consistent with previous studies of the responses of Aleppo pine to increased drought, which have extensively documented a reduction in growth and wood production as water availability decreases (Borghetti et al. 1998; De Luis et al. 2007; Sarris et al., 2007; Camarero et al., 2010, Pasho et al. 2012, Gazol et al. 2017, Novak et al. 2016, Peña Gallardo et al. 2018) and with the effects of climatic oscillators on tree growth trends in this area (reviewed in Camarero et al. 2011; Pasho et al. 2011, St George 2014, Madrigal-González et al. 2017, Dorado-Liñán et al. 2017). Extending this previous evidence, our results highlight a critical importance of sustained, multidecadal negative effects of climatic teleconnections in forest carbon capture and resilience patterns (Fig. 2). We suggest that multiple and non-mutually exclusive mechanisms are jointly operating at different time scales shaping the reported trends on forest carbon capture, including the three analyzed climatic mechanisms (Fig. 6), but also lagged effects of soil hydrological and tree ecophysiological processes (Fig. 6). Referring to the ecophysiological processes, major negative effects of drought on the secondary growth of Aleppo pine have been mainly reported at a 8-12 month time scale after drought, but significant effects have been documented for longer time periods (lasting to 24-30 months; Pasho et al. 2011, Peña Gallardo et al. 2018). Experimental, xylogenesis and isotope studies indicate that wood formation and secondary growth are 
significantly constrained by early summer water availability and associated with drought-induced shifts in the stomatic control of leaf conductance (Borghetti et al. 1998, Ferrio et al. 2003, Gazol et al. 2017, Novak et al. 2016). Similarly, it is well documented in this species that climatic conditions during the growing season affect tree growth during the subsequent year (Sarris et al. 2007, Linares et al. 2010, Pasho et al. 2011). In line with these findings, Anderegg et al. (2015) also documented in a global comparative analysis of multiple forest types an incomplete forest growth recovery for 1 to 4 years after extreme drought, showing most prevalent negative effects in Pinaceae species, located in dry ecosystems, and in species with reduced hydraulic safety margins. On top of this, additional observational studies suggest that complex feedbacks between drought-induced defoliation, tree primary and secondary growth and carbon starvation might extend and lengthen tree recovery periods, limiting tree long-term resilience, and resulting in declining trends (e.g. Girard et al. 2009, Guada et al. 2016). Independently from these ecophysiological processes, intrinsically delayed responses of soil hydrological systems, affecting groundwater levels several months after the meteorological drought can also additionally contribute to the emergence of long-term tree responses (St George et al. 2014). The limited early warning signals, low recovery rates and resilience trends reported for Aleppo pine (Figs. 2, 3) are consistent with previous studies (Camarero et al. 2015a, Gazol et al. 2018). Overall, despite the well-known importance of the reviewed ecophysiological processes shaping long-term responses of secondary growth, our analyses suggest a major contributing role of the reported climatic mechanisms on the reported regime shift (Fig. 4-6).

This article is protected by copyright. All rights reserved. 
Previous studies of the dynamics of forest carbon uptake in the Iberian peninsula have mainly focused on the 1986-2008 time period, i.e. the decades covered by the Spanish Forest National Inventories. These studies have reported dominant effects on tree secondary growth of stand structure, plantation effects, tree height, and functional diversity (reviewed in Gómez-Aparicio et al. 2011, Vayreda et al. 2012, Coll et al. 2013, Ruiz-Benito et al. 2014), and significant but quantitatively less dominant effects of climatic variables (Vayreda et al. 2012, Coll et al. 2013). Our results identify a new ecological context dominated by strong, climate-induced multidecadal shifts in forest productivity, with important reductions in annual productivity at the decadal scale (31-37\%) and significantly reduced resilience in Aleppo pine stands (Fig 2).

To conclude, in this study we have identified the key role of the non-stationary interactions between AMO and ENSO events in driving abrupt climatic shifts in semiarid Aleppo pine forests, providing a new, unreported mechanism for carbon uptake shifts in these vulnerable forests. We have provided as well evidence for other coacting processes implied in the emergence of regime shifts in drought and forest carbon uptake, and outlined a framework integrating the expected effects of global warming in these mechanisms.

This article is protected by copyright. All rights reserved. 


\section{References}

Ahlström A, Raupach MR, Schurgers G (2015) The dominant role of semi-arid ecosystems in the trend and variability of the land CO2 sink. Science, 348, 895-899.

Anderegg WR, Schwalm C, Biondi F et al. (2015) Pervasive drought legacies in forest ecosystems and their implications for carbon cycle models. Science, 349, 528-532.

Bamber J, den Broeke M, Ettema J, Lenaerts J, Rignot E (2012) Recent large increases in freshwater fluxes from Greenland into the North Atlantic. Geophysical Research Letters, 39, 19.

Bastos A, Running SW, Gouveia C, Trigo RM (2013) The global NPP dependence on ENSO: La Niña and the extraordinary year of 2011. Journal of Geophysical Research, 118, $1247-1255$.

Bjerknes J (1964) Atlantic air-sea interaction. Advances in Geophysics, 10, 1-82.

Borghetti M, Cinnirella S, Magnani F, Saracino A (1998) Impact of long-term drought on xylem embolism and growth in Pinus halepensis Mill. Trees, 12, 187-195.

Boulton CA, Lenton TM (2015) Slowing down of North Pacific climate variability and its implications for abrupt ecosystem change. Proceedings of the National Academy of

This article is protected by copyright. All rights reserved. 
Sciences USA, 112, 11496-11501.

Caesar L, Rahmstorf S, Robinson A, Feulner G, Saba V (2018) Observed fingerprint of a weakening Atlantic Ocean overturning circulation. Nature, 556, 191.

Cai W, Santoso A, Wang G, et al. (2015) ENSO and greenhouse warming. Nature Climate Change, 5, 849-859.

Camarero JJ, Olano JM, Parras A (2010) Plastic bimodal xylogenesis in conifers from continental Mediterranean climates. New Phytologist, 185, 471-480.

Camarero J J (2011) Direct and indirect effects of the North Atlantic Oscillation on tree growth and forest decline in northeastern Spain. In Hydrological, Socioeconomic and Ecological Impacts of the North Atlantic Oscillation in the Mediterranean Region (pp. 129-152). Springer, Dordrecht.

Camarero JJ, Gazol A, Sangüesa-Barreda G, Oliva J, \& Vicente-Serrano SM (2015a)

To die or not to die: early warnings of tree dieback in response to a severe drought. Journal of Ecology, 103, 44-57.

Camarero JJ, Gazol A, Galván JD, Sangüesa Barreda G, \& Gutiérrez E (2015b) Disparate effects of global change drivers on mountain conifer forests: warming induced growth enhancement in young trees vs. $\mathrm{CO}_{2}$ fertilization in old trees from wet

This article is protected by copyright. All rights reserved. 
sites. Global Change Biology, 21, 738-749.

Cassou C, Terray L, Phillips, AS (2005) Tropical Atlantic influence on European heat waves. Journal of Climate, 18, 2805-2811.

Chen X, Tung K (2014) Varying planetary heat sink led to global-warming slowdown and acceleration. Science, 345, 897-903.

Coll M, Peñuelas J, Ninyerola M, Pons X, Carnicer J (2013) Multivariate effect gradients driving forest demographic responses in the Iberian Peninsula. Forest Ecology and Management, 303, 195-209.

Coomes DA, Flores O, Holdaway R, Jucker T, Lines ER \& Vanderwel MC (2014) Wood production response to climate change will depend critically on forest composition and structure. Global Change Biology, 20, 3632-3645.

Coumou D, Lehmann J, Beckmann J (2015) The weakening summer circulation in the Northern Hemisphere mid-latitudes. Science, 348, 324-327.

Dakos V, Carpenter SR, Brock WA, et al. (2012) Methods for detecting early warnings of critical transitions in time series illustrated using simulated ecological data. PLoS

This article is protected by copyright. All rights reserved. 
ONE, 7, e41010.

De'ath G, Fabricius KE (2000) Classification and regression trees: a powerful yet simple technique for ecological data analysis. Ecology, 81, 3178-3192.

De Luis M, Gričar J, Čufar K, Raventós J (2007) Seasonal dynamics of wood formation in Pinus halepensis from dry and semi-arid ecosystems in Spain. Iawa Journal, 28, 389404.

Domingo-Marimón C (2016) Contributions to the knowledge of the multitemporal spatial patterns of the Iberan Peninsula droughts from a Geographic Information Service perspective. $\mathrm{PhD}$ thesis, University of Barcelona.

Dorado-Liñán I, Zorita E, Martínez-Sancho E. et al. (2017) Large-scale atmospheric circulation enhances the Mediterranean East-West tree growth contrast at rear-edge deciduous forests. Agricultural and Forest Meteorology, 239, 86-95.

Ferrio JP, Florit A, Vega A, Serrano L, Voltas J (2003) $\Delta 13$ C and tree-ring width reflect different drought responses in Quercus ilex and Pinus halepensis. Oecologia $137,512-518$.

Francis JA, Vavrus SJ (2012) Evidence linking Arctic amplification to extreme weather in mid-latitudes. Geophysical Research Letters, 39, 6.

This article is protected by copyright. All rights reserved. 
Francis JA, Vavrus SJ, Cohen J (2017). Amplified Arctic warming and mid-latitude weather: new perspectives on emerging connections. Wiley Interdisciplinary Reviews: Climate Change.

Frauen C, Dommenget D, Tyrrell N, Rezny M, Wales S (2014). Analysis of the nonlinearity of El Niño-Southern Oscillation teleconnections. Journal of Climate, 27, $6225-6244$.

Fu R (2015) Global warming-accelerated drying in the tropics. Proceedings of the National Academy of Sciences USA, 112, 3593-3594.

Gazol A, Ribas M, Gutiérrez E, Camarero JJ (2017) Aleppo pine forests from across Spain show drought-induced growth decline and partial recovery. Agricultural and forest meteorology, 232, 186-194.

Gazol A, Camarero JJ, Vicente-Serrano SM, et al. (2018) Forest resilience to drought varies across biomes. Global Change Biology, 24, 2143-2158.

Girard F, Vennetier M, Guibal F, Corona C, Ouarmim S, Herrero A (2012) Pinus halepensis Mill. crown development and fruiting declined with repeated drought in Mediterranean France. European Journal of Forest Research, 131, 919-931.

This article is protected by copyright. All rights reserved. 
Gómez-Aparicio L, García-Valdés R, Ruíz-Benito P, Zavala MA (2011) Disentangling the relative importance of climate, size and competition on tree growth in Iberian forests: implications for forest management under global change. Global Change Biology, 17, 2400-2414.

Guada G, Camarero JJ, Sánchez-Salguero R, Cerrillo RMN (2016) Limited growth recovery after drought-induced forest dieback in very defoliated trees of two pine species. Frontiers in Plant Science, 7, 418.

Gulev SK, Latif M, Keenlyside N, Park W, Koltermann KP (2013) North Atlantic Ocean control on surface heat flux on multidecadal timescales. Nature, 499, 464.

Häkkinen S, Rhines PB, Worthen DL (2011) Atmospheric blocking and Atlantic multidecadal ocean variability. Science, 334, 655-659.

Hansen J, Sato M, Hearty P, et al. (2016) Ice melt, sea level rise and superstorms: evidence from paleoclimate data, climate modeling, and modern observations that $2 \mathrm{C}$ global warming could be dangerous. Atmospheric Chemical Physics, 16, 3761-3812.

Hashimoto H, Nemani RR, White MA, et al. (2004) El Nino-Southern Oscillationinduced variability in terrestrial carbon cycling. Journal of Geophysical Research, 109, D23.

This article is protected by copyright. All rights reserved. 
Hoerling MP, Kumar A, Xu TY (2001) Robustness of the nonlinear climate response to ENSO's extreme phases. Journal of Climate, 14, 1277-1293.

Holmes RL (1983) Computer-assisted quality control in tree-ring dating and measurement. Tree-Ring Bulletin, 43, 69-75.

Keenan TF, Prentice IC, Canadell JG, et al. (2016) Recent pause in the growth rate of atmospheric $\mathrm{CO} 2$ due to enhanced terrestrial carbon uptake. Nature Communications, 7, 13428 .

Kim JS, Kug JS, Jeong, SJ et al. (2017) Reduced North American terrestrial primary productivity linked to anomalous Arctic warming. Nature Geoscience, 10, 572-576.

Kitzberger T, Brown PM, Heyerdahl EK, Swetnam TW, Veblen TT (2007) Contingent Pacific-Atlantic Ocean influence on multicentury wildfire synchrony over western North America. Proceedings of the National Academy of Sciences USA, 104, 543-548.

Lau WK, Kim KM (2015) Robust Hadley Circulation changes and increasing global dryness due to $\mathrm{CO} 2$ warming from CMIP5 model projections. Proceedings of the National Academy of Sciences USA, 112, 3630-3635.

Lenton TM, Held H, Kriegler E, Hall JW, Lucht W, Rahmstorf S, Schellnhuber HJ (2008) Tipping elements in the Earth's climate system. Proceedings of the National

This article is protected by copyright. All rights reserved. 
Academy of Sciences USA, 105, 1786-1793.

Li J, Sun C, Jin FF (2013) NAO implicated as a predictor of Northern Hemisphere mean temperature multidecadal variability. Geophysical Research Letters, 40, 5497 5502.

Linares JC, Delgado-Huertas A, Carreira JA (2011) Climatic trends and different drought adaptive capacity and vulnerability in a mixed Abies pinsapo-Pinus halepensis forest. Climatic change, 105, 67-90.

Lloret F, Keeling EG, Sala A (2011) Components of tree resilience: effects of successive low growth episodes in old ponderosa pine forests. Oikos, 120, 1909-1920.

López-Parages J, Rodríguez-Fonseca B (2012) Multidecadal modulation of El Niño influence on the Euro-Mediterranean rainfall. Geophysical Research Letters, 39, 2.

López-Parages J, Rodríguez-Fonseca B, Terray L (2015) A mechanism for the multidecadal modulation of ENSO teleconnection with Europe. Climate Dynamics, $\mathbf{4 5}$, $867-880$.

López-Parages J, Rodríguez-Fonseca B, Dommenget D, Frauen C (2016) ENSO influence on the North Atlantic European climate: a non-linear and non-stationary approach. Climate Dynamics, 47, 2071-2084.

This article is protected by copyright. All rights reserved. 
Madrigal-González J, Ballesteros-Cánovas JA, Herrero A et al. (2017). Forest productivity in southwestern Europe is controlled by coupled North Atlantic and Atlantic Multidecadal Oscillations. Nature Communications, 8, 2222.

Mann ME, Zhang Z, Rutherford S, et al. (2009) Global signatures and dynamical origins of the Little Ice Age and Medieval Climate Anomaly. Science, 326, 1256-1260.

Marsicek J, Shuman BN, Bartlein PJ, Shafer SL, \& Brewer S (2018) Reconciling divergent trends and millennial variations in Holocene temperatures. Nature, 554, 92.

Mariotti A, Zeng N, \& Lau KM (2002) Euro-Mediterranean rainfall and ENSO-a seasonally varying relationship. Geophysical Research Letters, 29, 59-1.

McCabe GJ, Palecki MA, Betancourt JL (2004) Pacific and Atlantic Ocean influences on multidecadal drought frequency in the United States. Proceedings of the National Academy of Sciences USA, 101, 4136-4141.

McPhaden MJ (2015) Playing hide and seek with El Niño. Nature Climate Change, 5, 791.

Montero G, Ruiz-Peinado R, Muñoz M (2005) Producción de biomasa y fijación de

This article is protected by copyright. All rights reserved. 
$\mathrm{CO}_{2}$ por los bosques españoles. Instituto Nacional de Investigación y Tecnología Agraria y Alimentaria, Madrid.

Moore GWK, Halfar J, Majeed H, Adey W, Kronz, A (2017). Amplification of the Atlantic Multidecadal Oscillation associated with the onset of the industrial-era warming. Scientific Reports, 7, 40861.

Novak K, De Luis M, Saz MA et al. (2016) Missing rings in Pinus halepensis-the missing link to relate the tree-ring record to extreme climatic events. Frontiers in Plant Science, 7, 727.

Pan Y, Birdsey RA, Fang J, et al. (2011) A large and persistent carbon sink in the world's forests. Science, 333, 988-993.

Pasho E, Camarero, JJ, de Luis M, Vicente-Serrano, SM (2011) Spatial variability in large-scale and regional atmospheric drivers of Pinus halepensis growth in eastern Spain. Agricultural and Forest Meteorology, 151, 1106-1119.

Pasho E, Camarero JJ, Vicente-Serrano SM (2012) Climatic impacts and drought control of radial growth and seasonal wood formation in Pinus halepensis. Trees, 26, 1875-1886.

This article is protected by copyright. All rights reserved. 
Peings Y, Magnusdottir G (2014) Forcing of the wintertime atmospheric circulation by the multidecadal fluctuations of the North Atlantic ocean. Environmental Research Letters, 9, 034018 (2014).

Peña-Gallardo M, Vicente-Serrano S, Camarero J. et al. (2018) Drought sensitiveness on forest growth in peninsular Spain and the Balearic Islands. Forests, 9, 524.

Poli P, Hersbach H, Dee DP, et al. (2016) ERA-20C: An atmospheric reanalysis of the twentieth century. Journal of Climate, 29, 4083-4097.

Poulter B, Frank D, Ciais P, et al. (2014) Contribution of semi-arid ecosystems to interannual variability of the global carbon cycle. Nature, 509, 600-603.

Power S, Haylock M, Colman R, Wang X (2006) The predictability of interdecadal changes in ENSO activity and ENSO teleconnections. Journal of Climate, 19, 47554771.

Quan XW, Diaz HF, Hoerling MP (2004) Change in the tropical Hadley cell since 1950. In: The Hadley circulation: present, past and future (eds. Diaz HS, Bradley RS), pp. 85-120, Springer, Netherlands.

Rahmstorf S, Feulner G, Mann, ME, Robinson A, Rutherford S, Schaffernicht EJ (2015) Exceptional twentieth-century slowdown in Atlantic Ocean overturning

This article is protected by copyright. All rights reserved. 
circulation. Nature Climate Change, 5, 475-480.

R Development Core Team (2016) R: A Language and Environment for Statistical Computing. R Foundation for Statistical Computing, Vienna.

Ribas M. (2006) Dendroecology of Pinus halepensis Mill. in the Eastern Iberian Peninsula and Balearic Islands: sensitivity and adaptation to climatic conditions. University of Barcelona. $\mathrm{PhD}$

Robson J, Sutton R, Smith D (2014) Decadal predictions of the cooling and freshening of the North Atlantic in the 1960s and the role of ocean circulation. Climate Dynamics, 42, 2353-2365.

Rodríguez-Fonseca B, Suárez-Moreno R, Ayarzagüena B, et al. (2016) A review of ENSO influence on the North Atlantic. A non-stationary signal. Atmosphere, 7, 87.

Ruiz-Benito P, Gómez-Aparicio L, Paquette A et al. (2014) Diversity increases carbon storage and tree productivity in S panish forests. Global Ecology and Biogeography, 23, 311-322.

SAS Institute (2012) JMP. Cary, NC, SAS Institute Inc. 
Sarris D, Christodoulakis D, Körner C (2007) Recent decline in precipitation and tree growth in the eastern Mediterranean. Global Change Biology, 13, 1187-1200.

Scheffer M, Bascompte J, Brock WA, et al. (2009) Early-warning signals for critical transitions. Nature, 461, 53-59.

Screen JA, Francis JA (2016) Contribution of sea-ice loss to Arctic amplification is regulated by Pacific Ocean decadal variability. Nature Climate Change, 6, 856-860.

Sgubin G, Swingedouw D, Drijfhout S, Mary Y, \& Bennabi A (2017) Abrupt cooling over the North Atlantic in modern climate models. Nature Communications, 8, 14375.

Sherwood S, Fu Q (2014) A drier future? Science, 343, 737-739.

St George, S. (2014) An overview of tree-ring width records across the Northern Hemisphere. Quaternary Science Reviews, 95, 132-150.

Su J, Zhang R, \& Wang H (2017) Consecutive record-breaking high temperatures marked the handover from hiatus to accelerated warming. Scientific Reports, 7, 43735.

Sun C, Kucharski F, Li J, Jin FF, Kang IS, Ding R. (2017) Western tropical Pacific

This article is protected by copyright. All rights reserved. 
multidecadal variability forced by the Atlantic multidecadal oscillation. Nature Communications, 8, 15998.

Sutton RT, Hodson DLR (2005) Atlantic Ocean forcing of North American and European summer climate. Science, 309, 115-118.

Sutton RT, Dong B (2012) Atlantic Ocean influence on a shift in European climate in the 1990s. Nature Geoscience, 5, 788-792.

Thornalley DJ, Oppo DW, Ortega P, et al. (2018) Anomalously weak Labrador Sea convection and Atlantic overturning during the past 150 years. Nature, 556, 227.

Tokinaga H, Xie SP, Mukougawa H (2017) Early 20th-century Arctic warming intensified by Pacific and Atlantic multidecadal variability. Proceedings of the National Academy of Sciences USA, 114, 6227-6232.

Vayreda J, Martinez-Vilalta J, Gracia M, \& Retana J (2012) Recent climate changes interact with stand structure and management to determine changes in tree carbon stocks in Spanish forests. Global Change Biology, 18, 1028-1041.

Vicente-Serrano SM, Beguería S, López-Moreno JIA (2010) A multiscalar drought index sensitive to global warming: the standardised precipitation evapotranspiration index. Journal of Climate, 23, 1696-1718.

This article is protected by copyright. All rights reserved. 
Wang B, Liu J, Kim HJ, Webster PJ, Yim SY, Xiang B (2013) Northern Hemisphere summer monsoon intensified by mega-El Niño/southern oscillation and Atlantic multidecadal oscillation. Proceedings of the National Academy of Sciences USA, 110, $5347-5352$.

Wang C (2002) Atmospheric circulation cells associated with the El Niño-Southern Oscillation. Journal of Climate, 15, 399-419.

\section{Acknowledgments}

We would like to thank AEMET for providing the meteorological station series. This research was supported by the Spanish Government (MINECO/FEDER) projects CGL2013-48074-P, CGL013-48277-P, CGL2010-17172, CGL2011-26654, CGL201233927, CGL2015-69888-P, CGL2016-78093-R, Consolider Ingenio Montes (CSD2008-00040), the Spanish Government FPU grant AP2008-2016 to CDM, the Catalan Government grants SGR2009-458, SGR2017-1690, SGR2017-1005 and FI2013, the European Research Council Synergy grant IMBALANCE-P (610028), the VENI-NWO 863.11.02 grant, and the EU H2020 projects ForMAT (ENV4-CT970641) and ECOPOTENTIAL (641762). This work was performed under the $\mathrm{PhD}$ programme for CDM in Geography at the Universitat Autònoma de Barcelona. XP is the recipient of an ICREA Academia Excellence in Research Grant (2016-2020 and 2011-2015)

This article is protected by copyright. All rights reserved. 


\section{Figure captions}

FIGURE 1. Drought-regime shifts. Observed shifts in monthly series of the Standard Precipitation Evapotranspiration Index (SPEI, 12-month window) at a grid resolution of $280 \times 280 \mathrm{~km}^{2}$ in the Spanish Iberian Peninsula. The year of a shift and the variance explained by the regression tree model are indicated. The splitting points obtained by the regression tree analyses for 1950-2012 are indicated by coloured vertical bars. Red bars indicate shifts characterized by $R^{2}>0.20$ and a Tukey-Kramey test $p$ value $<0.0001$. Orange bars indicate significant shifts with regression tree $0.10<R^{2}<0.20$ and a T-K test $p$ value $<0.0001$. Yellow bars indicate $0.01<R^{2}<0.10$ and a T-K test $\mathrm{p}$ value $<0.0001$. Green bars indicate a splitting point departing from the studied $1979-1981$ period. Positive and Negative SPEI values indicate wet and dry periods, respectively. (a-m) Monthly SPEI series are shown for each grid unit.

FIGURE 2. Changes in carbon uptake by Mediterranean forests. (a) Carbon-uptake dynamics in 18 Aleppo pine forests situated in the northeastern Iberian Peninsula showing regime shifts in carbon uptake. Blue dots and lines represent the observed trends in carbon gain during the first three decades. Red dots and lines illustrate the observed dynamics after the 1980s climate shift. Significant linear trends are shown (ordinary least squares regression). Smoothed trends fitted by the cubic spline method are represented ( $\lambda$ values $=0.01$ and 100). (b) Observed trends in forest carbon uptake shynchrony. A spline fit (black line) indicates the averaged $r$ pearson trend observed for all forest stands $(\lambda=100)$. The contour lines are quantile contours in 5\% intervals (i.e. $5 \%$ of the $\mathrm{r}$ pearson values are below the lowest (blue) contour, $10 \%$ are below the next contour, red contour lines indicate maximum point density). (c) Observed trends in the 
forest carbon uptake resilience index after the 1980 regime shift. A spline fit (black line) indicates the mean FCUR trend observed for all forest stands $(\lambda=100)$. FCUR is calculated using a reference period of 5 years before the shift. A smooth coloured surface illustrating the density distribution of FCUR values is provided. Red contour lines indicate maximum FCUR point density. The contour lines are quantile contours in 5\% intervals. (d) Observed trends in forest carbon uptake recovery capacity (FCURC). The thin dashed black line indicates the minimum FCU level observed the year of the regime shift. A spline fit (black line) indicates the averaged FCURC trend observed for all forest stands $(\lambda=100)$. Red contour lines indicate maximum FCURC point density.

\section{FIGURE 3. Analyses of early-warning signals and structural equation models}

(SEM). (a) A comparison of the early-warning signals (AR-1) observed for SPEI variables and forest carbon uptake $\left(\mathrm{kg} \mathrm{ha}^{-1} \mathrm{y}^{-1}\right)$. (b) Observed relationship between SPEI early-warning signals (AR-1) and regime shift strength (variance explained by regression tree models). (c) Relationship between the nonparametric Kendall tau correlation coefficient for the AR-1 moment (based on the SPEI 12-month time series during the 1950-1979 period) and the variance explained by the regression tree models (1/AICc). (d) Standardised coefficients in the SEM model for grid cell $\mathrm{g}\left(280 \times 280 \mathrm{~km}^{2}\right.$ scale, Supplementary Fig. 1). Model-fitting parameters: $\chi^{2}=3.04, p=0.36 ; \mathrm{BIC}=-16.81$.

(e) Relationship between the standardised coefficients in the SEM models linking AMO and SPEI and the variation explained by the regression tree analyses (1/AICc). (f) Relationship between the nonparametric Kendall tau correlation coefficient and the standardised coefficients of the SEM connecting AMO and SPEI 12.

This article is protected by copyright. All rights reserved. 
FIGURE 4. Changes in the non-stationary effects of the El Niño Southern Oscillation (ENSO) and the North Atlantic Oscillation (NAO) on the SPEI drought index. (a) Upper panel. Observed changes in the Atlantic Multidecadal oscillation (AMO) and the Multivariate ENSO Index (MEI) over 1950-2012, reporting a parallel shift in the vicinity of 1980 . Low-frequency variability in the annual AMO and MEI index are illustrated (Spline fits, Lambda $_{\mathrm{AMO}}=10$, Lambda $_{\mathrm{MEI}}=100$ ). Lower panel: Observed variation in the number of months per year with significant effects $(p<0.05)$ of the Multivariate ENSO index (MEI) on seasonal drought (SPEI, three month temporal scale). Red squares indicate significant negative effects associated with increased drought (increased number of months with significant drought effects). Blue squares indicate positive effects associated with increased autumn rains $(p<0.05)$. (b) Observed low frequency changes in the monthly winter NAO index over 1950-2012. Trends for January are illustrated (Spline fit). The same trends were observed for December (not shown). Thick blue line: Lambda=10000. Thin blue line: Lambda $=1000$. Lower panel: Observed variation in the effects of winter NAO on drought (SPEI 3). Significant negative effects of NAO on SPEI $(p<0.05)$ were detected on December and January. Red squares illustrate the detection of significant negative effects of monthly winter NAO states (December and January) on SPEI $(p<0.05)$.

\section{FIGURE 5. Modulation induced by the Atlantic ocean multidecadal variability (AMO) on the correlations between ENSO and forest carbon uptake (FCU). (a) Observed} negative correlations between Pearson correlation values (rFCU-MEI) and AMO in the 18 Aleppo pine stands experiencing regime shift trends. Correlations were computed for all months, and the maximum correlation value observed is illustrated. ${ }^{*} p<0.05$, ${ }^{* *} p<0.01$. (b) A summary of the observed variation of the strength of the modulation 
by AMO (explained variance) and its monthly variation. The plot synthesises the observed relationships at 18 forest sites and for all the months of the year. A quadratic polynomial fit is shown. (c) Observed $p$ values for the reported correlations in $b . \ln b$ and $\mathrm{c}$ a smooth surface showing the density of data points is provided. Red contour colors indicate maximum point density.

FIGURE 6. A diagram illustrating three mechanisms affecting drought trends and regime shifts in forest carbon uptake. Sea surface temperatures (SST) depend on positive/negative AMO phases and ENSO, and modulate the propagation of Rossby waves and the transport of water vapour and heat over land. AMO also has lagged effects on the dynamics of winter NAO, which in turn significantly affect drought severity and atmospheric blocking frequency leading to reduced forest carbon uptake.

This article is protected by copyright. All rights reserved. 


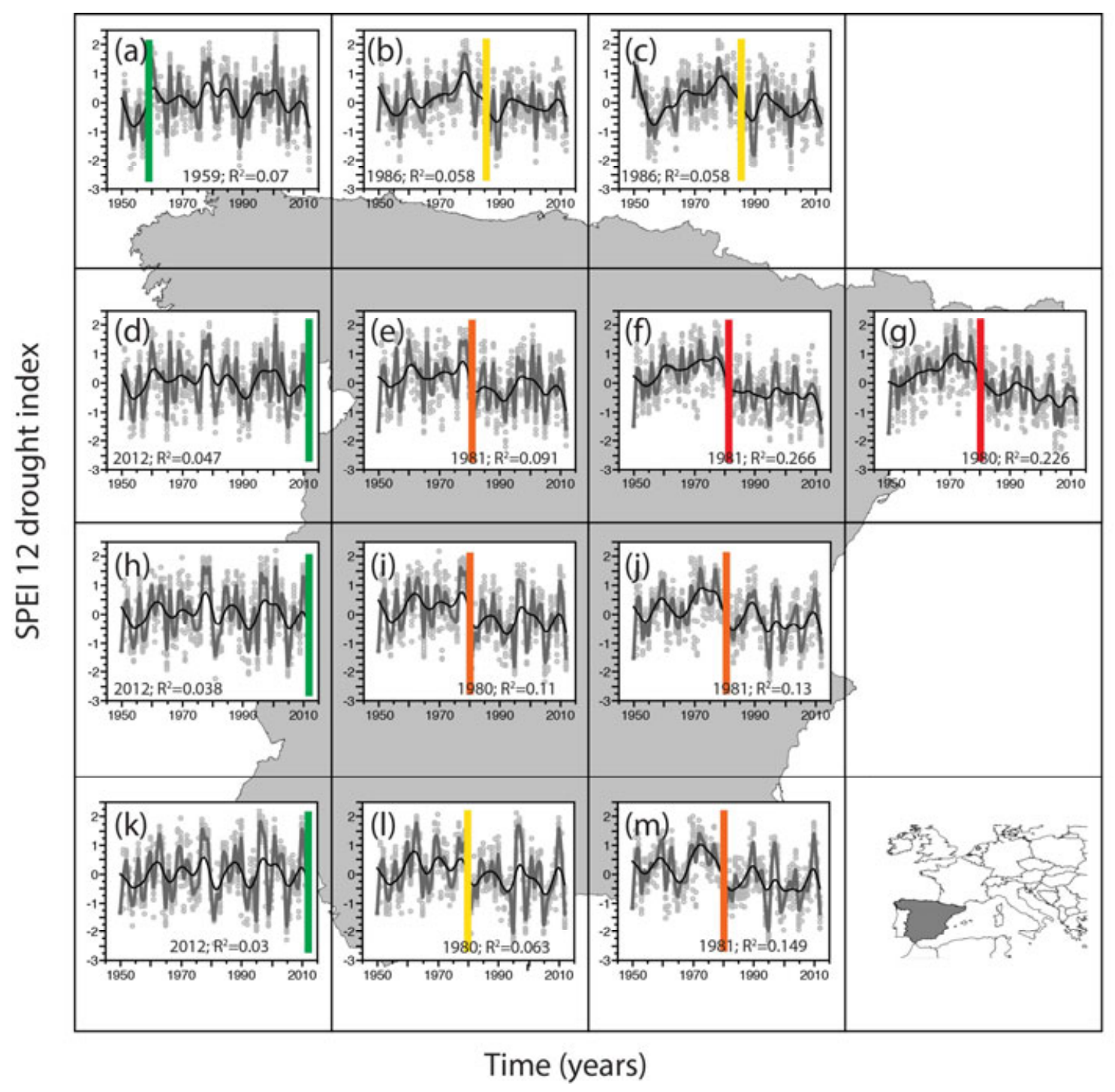

This article is protected by copyright. All rights reserved. 


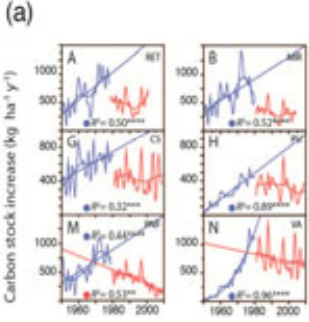

(b)

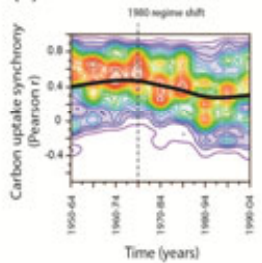

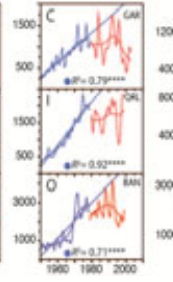

Time (yearsi

(c)

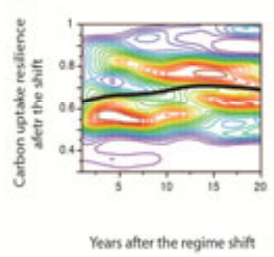

(d)
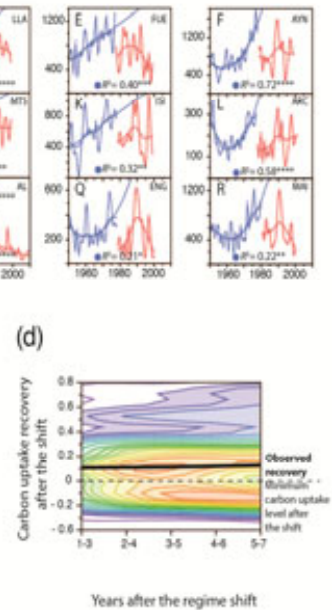

This article is protected by copyright. All rights reserved. 
(a)

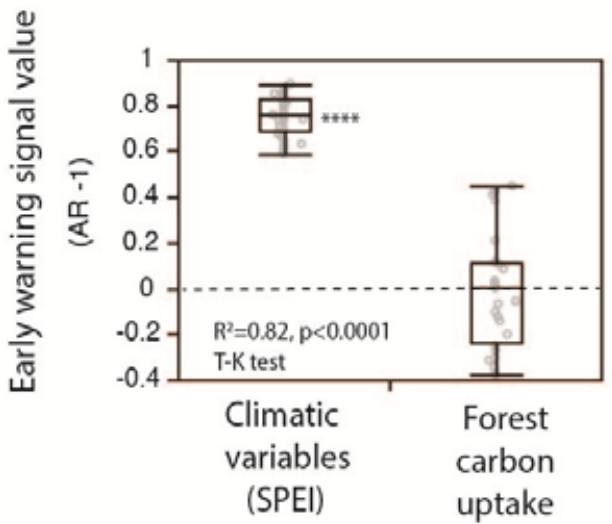

(c)

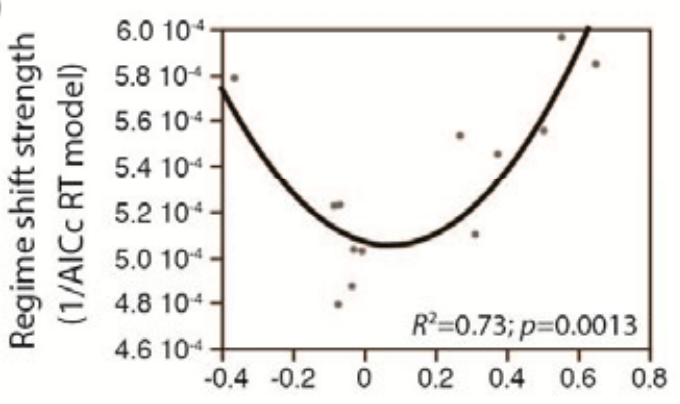

(e)

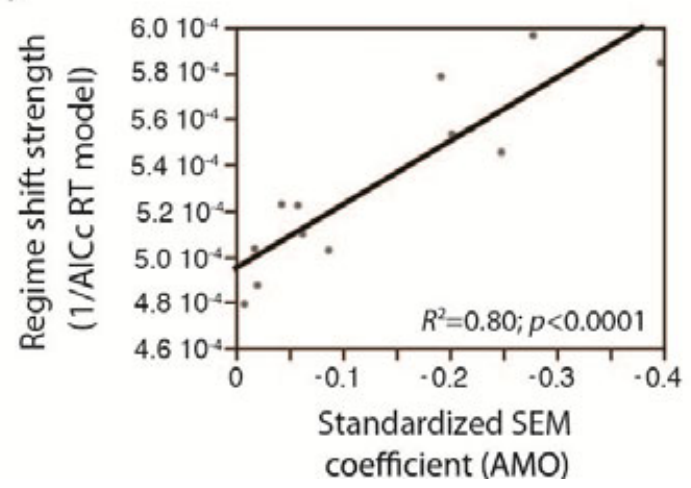

(b)

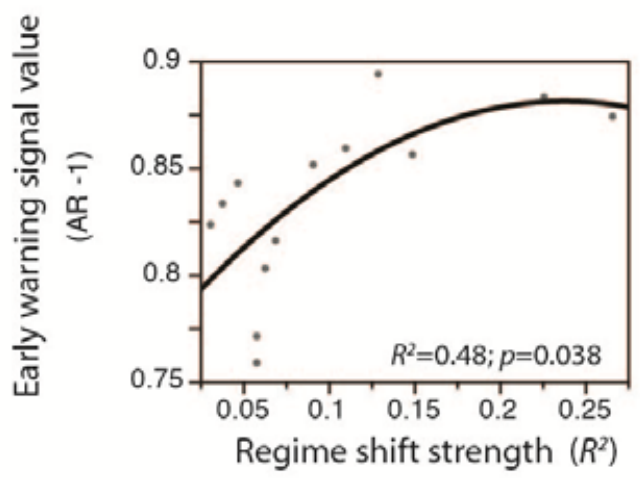

(d)

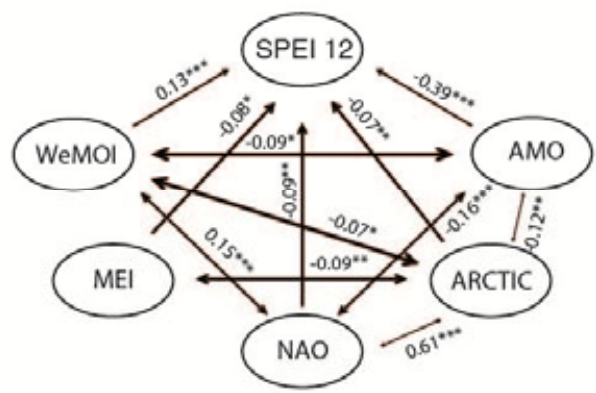

(f)

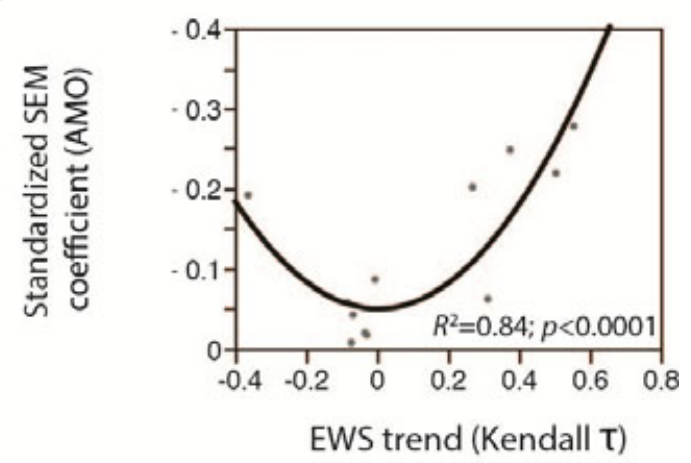

This article is protected by copyright. All rights reserved. 
(a)

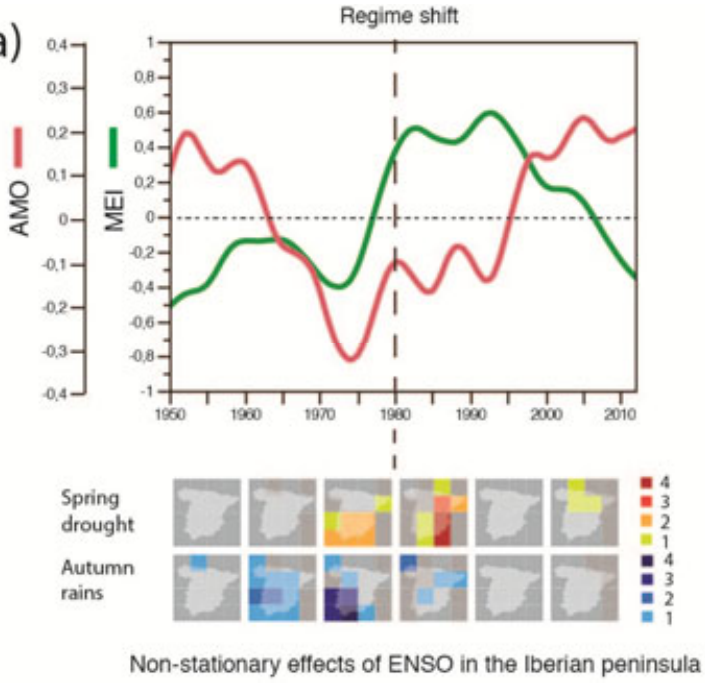

(b)

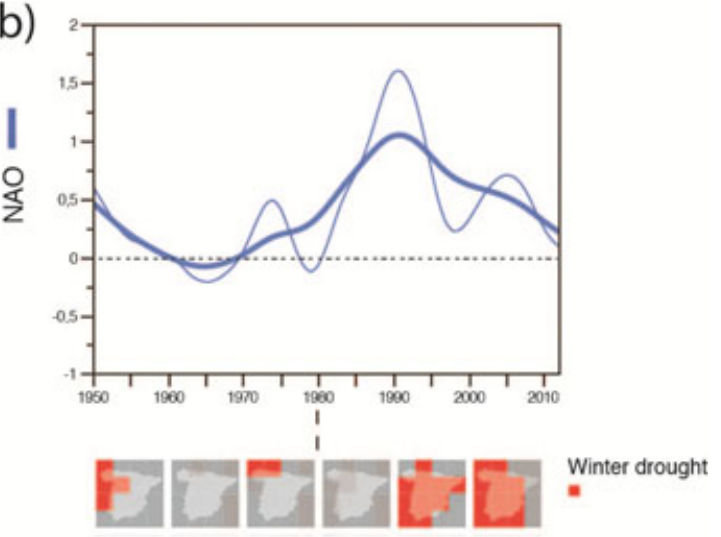

Non-stationary effects of NAO in the Iberian peninsula

This article is protected by copyright. All rights reserved. 
(a)
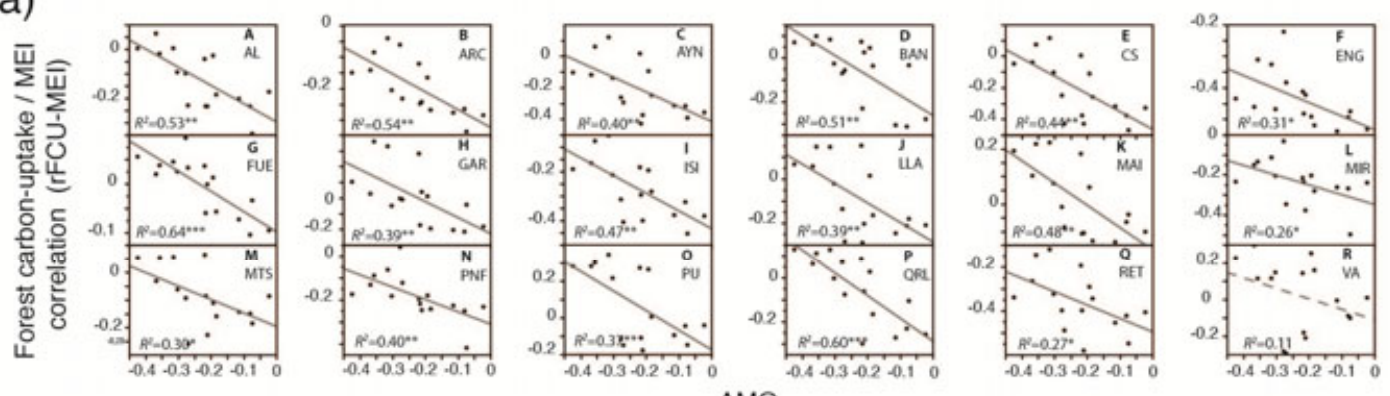

(b)
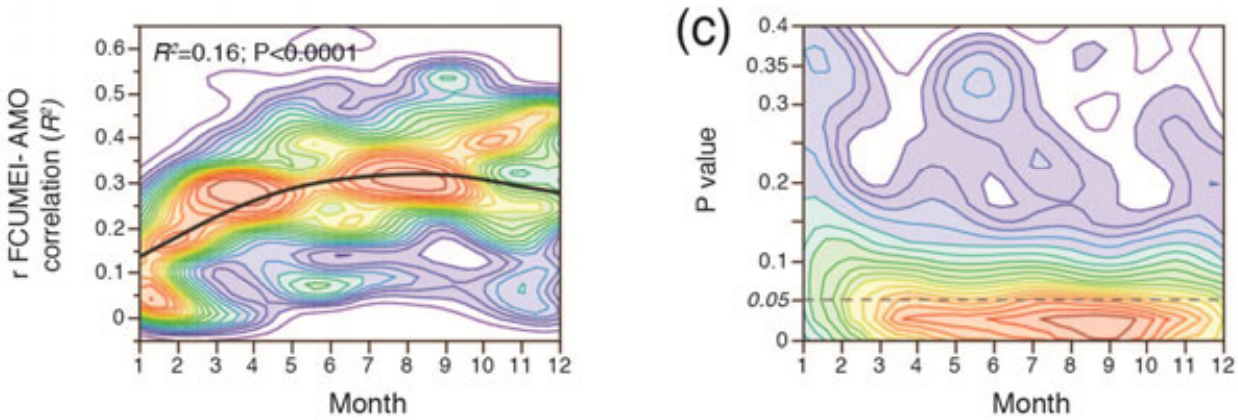

This article is protected by copyright. All rights reserved. 


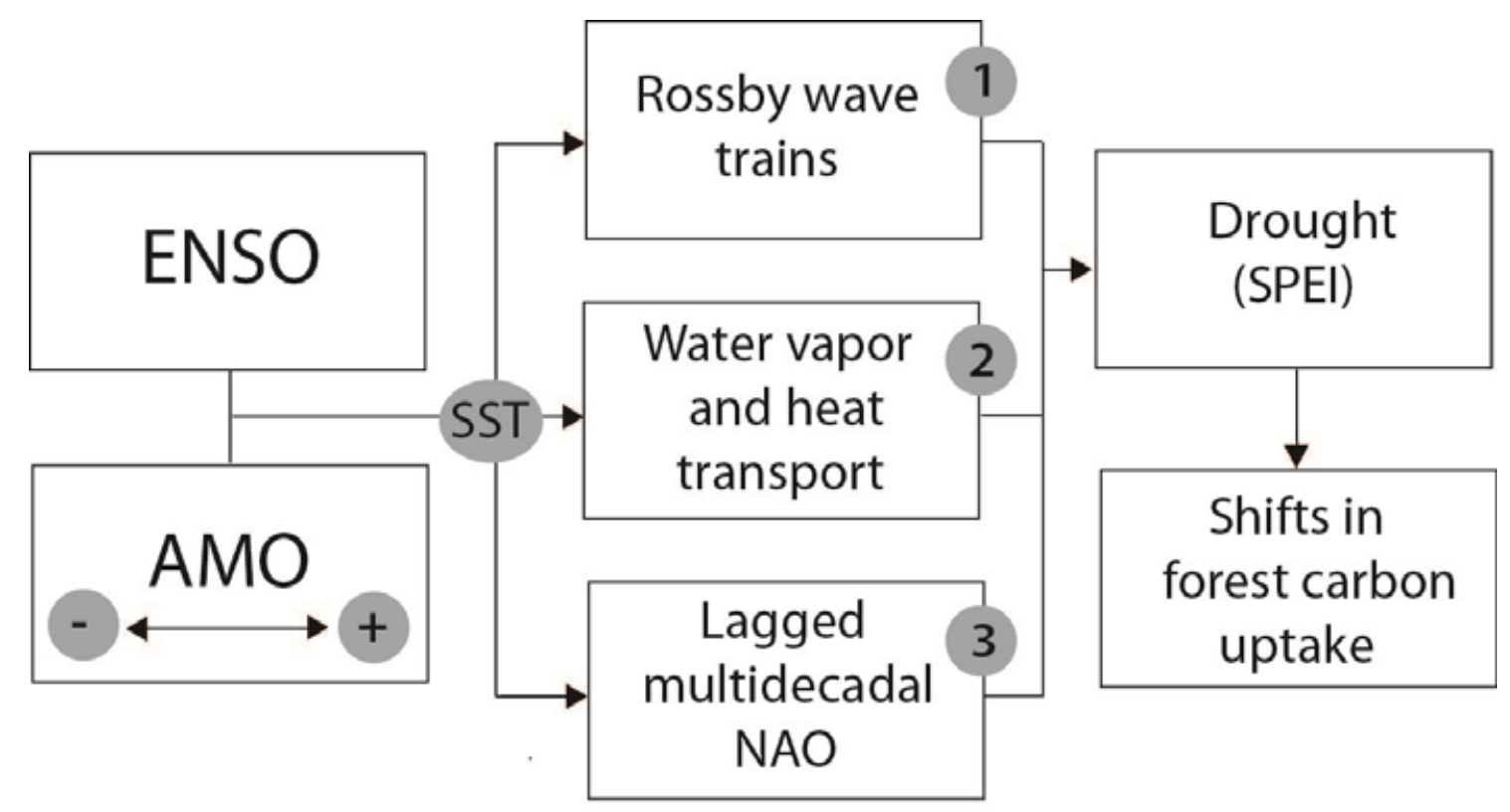

This article is protected by copyright. All rights reserved. 